\title{
The 16th Party Congress in China: A Note on Personnel Changes
}

\author{
KJELD ERIK BRøDSGAARD
}

At the recent 16th Party Congress a comprehensive change of the Chinese leadership was carried through. Even though there was much speculation as to whether Jiang Zemin and his generation would retire as scheduled, the change of the old guard took place without much drama when the congress finally convened in Beijing.

How do we evaluate this development? Does it mean that Chinese politics have matured in the sense that major decisions now conform to fixed rules and regulations rather than factional politics? Has the Chinese political process become more transparent? Have consensual decision-making processeses finally taken over, relegating patrimonial policies to a phenomenon of the past? Since the mid-1990s, clear and detailed regulations for the selection and appointment of leading cadres have been promulgated. Is the 16th Party Congress the final step in this process of procedural normativization? Before attempting to answer these questions, this paper will first deal with the personnel changes that took place at the 16th Party Congress and the Central Committee (CC) meeting shortly after the conclusion of the conference. ${ }^{1}$

\section{Composition of the Politburo Standing Committee}

On 15 November, the 16th Central Committee elected a new General Secretary and new members of the Politburo and the Politburo Standing Committee (PBSC). The new Standing Committee of the Politburo, the true ruling elite, consists of nine members (see Table 1). Eight of these have been moved up from the Politburo. Only $\mathrm{Hu}$ Jintao, the new general secretary, had a seat on the outgoing PBSC. Li Changchun is at 58 the youngest of the new PBSC members. Luo Gan has turned 67 and is the oldest. The average age is 62 , compared to an average age of 70 for the outgoing members.

The new general secretary, $\mathrm{Hu}$ Jintao, is often described by the Western news media as an enigmatic person whose beliefs and background are little known in the outside world. However, in China he is a wellknown public figure. Hu became a member of the CC in 1982 at the early age of 39. In 1992, only 49 years old, he again attracted attention 


\begin{tabular}{|c|c|c|}
\hline \multicolumn{3}{|c|}{$\begin{array}{l}\text { TABLE 1: Newly elected members of Standing Committee of CCP } \\
\text { Politburo (15 November 2002) }\end{array}$} \\
\hline Name & Position & Age \\
\hline Hu Jintao & general secretary, vice-president & 59 \\
\hline Wu Bangguo & vice-premier & 61 \\
\hline Wen Jiabao & vice-premier & 60 \\
\hline Jia Qinglin & former party secretary, Beijing & 62 \\
\hline Zeng Qinghong & former head, CC Organization Department & 63 \\
\hline Huang Ju & former party secretary, Shanghai & 64 \\
\hline Wu Guanzheng & former party secretary, Shandong & 64 \\
\hline Li Changchun & former party secretary, Guangdong & 58 \\
\hline Luo Gan & state councillor & 67 \\
\hline
\end{tabular}

when he was elected to the PBSC. This promotion was apparently suggested by Deng Xiaoping who regarded Hu Jintao as the core of the socalled fourth generation, i.e., the fourth generation that would eventually succeed the third generation with Jiang Zemin as its core.

That $\mathrm{Hu}$ for ten years has been able to maintain his position as core of the fourth generation of political leaders in China and the undisputed heir apparent is testimony to his political skills and acumen. In fact, $\mathrm{Hu}$ possesses the three core competences necessary to make it to the very top of the political system in China. First he has solid regional work experience; having worked in Gansu province for many years in the 1970s and early 1980s and by acting as party secretary in the provinces of Guizhou and Tibet. Second, Hu has worked in the Central Party and state bureaucracy in Beijing. Third, he holds a university degree which is a sine qua non for top party and state leaders in China today. In Hu's case he graduated from the prestigious Tsinghua University. In short, $\mathrm{Hu}$ possesses the experience and competences that are considered important for leading party cadres in China today.

The Politburo Standing Committee was expected to consist of seven members, but the CC decided to enlarge the top party organ to nine members. Apparently, when the decision was made to promote $\mathrm{Wu}$ Guanzheng, it was argued that Huang Ju and Jia Qinglin also had to follow suit. The three are approximately the same rank and it might have attracted criticism if only one of them had been promoted and the other two had been left on a Politburo where their former colleagues were either promoted or retired because they had reached the age limit. To prevent such an awkward situation, the decision was made to move up the 'whole class'. 
Seven members of the new PBSC are engineers by education and two have university degrees in geology and mining. Four of the engineers are from Tsinghua University. The four Tsinghua graduates are $\mathrm{Hu}$ Jintao, Wu Bangguo, Huang Ju and Wu Guanzheng. This has reinforced Tsinghua's reputation as being one of the major sources for elite recruitment in China today.

It is noteworthy that four of the new members of the PBSC until recently worked as provincial leaders (See Table 1). Hu Jintao and $\mathrm{Wu}$ Bangguo also share a background as provincial party leaders and Zeng Qinghong has served as deputy party secretary in Shanghai under Jiang Zemin. It will be interesting to see whether such strong regional experiences in the top policy-making body will result in attempts to focus more on the problems in the inner provinces.

It has been argued that five to six of the new members of the PBSC are members of Jiang's faction. These are: Wu Bangguo, who is ranked number two and will probably take over Li Peng's post as chairman of the NPC; Jia Qinglin who is slated for the position of head of the Chinese People's Political Consultative Conference (CPPCC); Zeng Qinghong who is in line to become vice-president when Hu succeeds Jiang as president next spring; the likely coming executive vice-premier Huang Ju; Li Changchun who will probably also be appointed vice-premier and most likely Wu Guanzheng, the new head of the disciplinary commission. Of the remaining three one is reported to be close to Zhu Rongji (Wen Jiabao, the likely future premier) and another to Li Peng (Luo Gan who most probably will be in charge of the legal and security portfolio). Hu Jintao is considered his own man. However, the five allegedly pro-Jiang members of the PBSC are perhaps really not that tight a Jiang clique. They all have their own agendas. Even Zeng Qinghong, who is considered a close confidant of Jiang, might have a (reform) agenda going beyond Jiang's ideas. ${ }^{2}$

Jia Qinglin and Huang Ju probably owe Jiang Zemin the most and from a factional point of view they may be the easiest to manipulate. However, Jia is tainted by having served as party secretary in Fujian province at the time of the big Yuanhua corruption case in Xiamen. Huang Ju reportedly also has some skeletons in his closet from his tenure as head of the party in Shanghai. Thus both may prove to be liabilities rather than assets for Jiang Zemin.

Luo Gan is reported to be close to Li Peng. However, even though he is the oldest among the new PBSC members, he ranks last. In fact, during last-minute horse-trading he was deprived of the much coveted 
position as head of the Central Discipline Inspection Committee. Instead the job went to $\mathrm{Wu}$ Guanzheng and Luo Gan ended up with a reduced legal and security portofolio. This outcome might be seen as a reflection of Li Peng's weakened position and it will be curious to see whether Luo Gan will be able to protect his mentor without controlling the Central Disciplinary Commission.

Wu Bangguo's position as number two indicates that he will be appointed head of the NPC when Li Peng retires next March. This was never a given thing as Li Ruihuan was in line for the job. Wu Bangguo's track record is not the best. As vice-premier he was tasked with reforming the SOEs, but has not managed to complete this important role. Due to his background as party leader in Shanghai 1991-95, Wu is widely regarded as a staunch ally of Jiang Zemin's. However, Wu also shares a background and experiences similar to Hu's, as they were both at Tsinghua at about the same time in the early 1960s.

Li Changchun is at 58 the youngest of the PBSC members. He is from the Northeast and was only 38 when he became mayor of Shenyang city. In 1992 he was appointed party secretary of Henan province. While he was serving in Henan, the present AIDS epidemic in the province broke out. However, Li Changchun was transferred to Guangdong in 1998, just in time to avoid being blamed for the problems of the province, and has been able to keep his career on track. But echoing the experiences of Jia Qinglin, his past might well have prevented his rise to the top had it not been for Jiang Zemin's support.

At one point Wen Jiabao's career also seemed to have peaked. This was in 1989 when, as head of the party's Central Office, he appeared together with Zhao Ziyang at Tiananmen Square to tell the students that it was all too late. However, he was able to dissociate himself from Zhao Ziyang so that the downfall of the former general secretary had no major repercussions for Wen Jiabao. Thus he was appointed vicepremier in 1998 and, under Zhu Rongji's direction, was assigned to rural work and attempts to reform the ailing bank sector.

It is rather surprising that Li Ruihuan did not manage to retain his Politburo seat. Li is only 67 years old (the age of Luo Gan) and has not yet reached the 70-year age limit which operates informally in China. However, Jiang wanted him to retire, fearing that he might use his status as the elder statesman in the new Politburo to advance his slightly veiled criticism of Jiang and the 'Three Representations'. Apparently Jiang used the argument that Li Ruihuan belonged to the outgoing third generation which has to give way to younger forces. 


\section{Composition of the new Politburo}

The Politburo, the second-highest seat of power, consists of the nine PBSC members plus 15 full PB members and one alternate (see Table 2 )

The Politburo has been completely reshuffled and the members who were not retired have been promoted. As indicated above, this is probably the main reason for enlarging the PBSC to nine members. All those who had not yet reached retirement age were simply moved up.

A third of the below-listed 24 members of the Politburo are regional party leaders. In the outgoing Politburo only four of the 20 full members were provincial leaders. They all came from eastern coastal provinces such as Shanghai, Beijing, Guangdong and Shandong. Now Shanghai, Beijing, Tianjin, Zhejiang, Jiangsu, Sichuan, Hubei and Xinjiang are represented with their party leaders. In addition He Guoqiang only recently was transferred from his position as party secretary in Chongqing to take up his present assignment as head of the Central Organization Department. The appointment of the Xinjiang and Hubei party secre-

\begin{tabular}{|l|l|c|}
\hline \multicolumn{2}{|l|}{ TABLE 2: Newly elected members of CCP Politburo (at 15 November 2002) } \\
\hline Name & Position & Age \\
\hline Hu Jintao & general secretary, vice-president & 59 \\
\hline Wu Bangguo & vice-premier & 61 \\
\hline Wen Jiabao & vice-premier & 60 \\
\hline Jia Qinglin & former party secretary, Beijing & 62 \\
\hline Zeng Qinghong & former head, CC Organization Department & 63 \\
\hline Huang Ju & former party secretary, Shanghai & 64 \\
\hline Wu Guanzheng & former party secretary, Shandong & 64 \\
\hline Li Changchun & former party secretary, Guangdong & 58 \\
\hline Luo Gan & state councillor & 67 \\
\hline Wang Lequan & party secretary, Xinjiang & 57 \\
\hline Wang Zhaoguo & head, CC United Front Department & 60 \\
\hline Hui Liangyu (hui) & party secretary, Jiangsu & 57 \\
\hline Liu Qi & party secretary, Beijing & 59 \\
\hline Liu Yunshan & head, CC Propaganda Department & 54 \\
\hline Wu Yi (female) & state councillor & 64 \\
\hline Zhang Lichang & party secretary, Tianjin & 62 \\
\hline Zheng Dejiang & party secretary, Zhejiang & 55 \\
\hline Chen Liangyu & party secretary, Shanghai & 55 \\
\hline Zhou Yongkang & party secretary, Sichuan & 59 \\
\hline Yu Zhengsheng & party secretary, Hubei & 57 \\
\hline He Guoqiang & head, CC Organization Department & 58 \\
\hline Guo Boxiong & vice-chairman, Central Military Commission & 59 \\
\hline Cao Gangchuan & vice-chairman, Central Military Commission & 66 \\
\hline Zhang Peiyan & minister, State Devel. Planning Commission & 63 \\
\hline Wang Gang (alternate) & head, CC General Office & 59 \\
\hline & & \\
\hline
\end{tabular}


taries as Politburo members is particularly noteworthy. These relatively poor inland provinces are normally not represented in the Politburo. In fact, this is the first time in the history of the PRC that Xinjiang has a full member of the Politburo. ${ }^{3}$

It has been reported that Zhang Dejiang has been moved to Guangdong, replacing Li Changchun. To replace Zhang Dejiang Xi Jinping has been appointed Zhejiang party secretary. Moreover, Zhang Gaoli has been moved to Shandong, Bai Keming to Hebei, and Wang Qishan to Hainan. These personnel changes mean that Guangdong has retained its Politburo status, whereas Shandong is no longer represented. Barring any major reshuffle, this picture represents a clear victory for the localities, especially the inner provinces.

Wang Lequan's promotion to the Politburo is a reflection of several important developments. First, Xinjiang has experienced a comparatively rapid economic development in recent years and is now one of the more wealthy of the inland provinces. Second, Xinjiang's increasingly strategic importance in the global war against anti-terrorism probably is an important factor. Thus it has been reported that Wang Lequan might be given more responsibilities in fighting terrorism. Third, Wang Lequan's presence on the Politburo might indicate that the new leadership is willing to pay closer attention to the problems in the poorer innner provinces. Hu Jintao made his career in the inner provinces, in particular Gansu, and might be more inclined than Jiang and his Shanghai group to push for a redistribution of funds and investment to the benefit of these regions. In this he will have the support of Wen Jiabao, who also worked in Gansu in the 1970s and early 1980s.

None of the so-called fifth-generation leaders, such as Zhao Leji (45, governor, Qinghai), Li Keqiang (47, party secretary, Henan), Xi Jinping (49, governor Fujian, now Zhejiang party secretary) and Bo Xilai (53, governor, Liaoning) made it to the Politburo. Apparently Jiang Zemin blocked such appointments, arguing it was too soon for these young regional leaders to move up the hierarchy. Also either they all had to be appointed or the top leadership would have had to make a decision on whom to consider the core of this new political generation and on this they could not agree.

It should also be noted that the new Politburo is weak on security and foreign policy expertise. Apparently, Wu Yi will be given the foreign policy portofolio. However, although she has extensive experiences on trade-related issues from her time as minister of foreign trade and external relations, she is not known as a foreign policy expert on a par 
with outgoing Vice-Premier Qian Qichen or Foreign Minister Tang Jiaxun. Given such a situation, Jiang Zemin and other elders will continue to have a role to play in foreign policy-making. Whether this will entail that Jiang will continue to chair some of the important leading small groups such as the national security leading group and the Taiwan leading small group remains to be seen.

\section{Central Military Commission}

The Central Military Commission (CMC) elected by the Central Committee consists of eight members. Jiang was re-elected chairman and $\mathrm{Hu}$ Jintao vice-chairman. There are two new vice-chairmen: Guo Boxiong, former executive deputy chief of the General Staff of the PLA, and Cao Gangchuan, former director of the General Armaments Department. They are both members of the new Politburo. The other new $\mathrm{CMC}$ members are generals $\mathrm{Xu}$ Caihou, director of the General Political Department, Liao Xilong, director of the General Logistics Department, and Li Jinai, director of the General Armaments Department and finally the new chief of general staff, Liang Guanglie. Liang has served as commander of the Nanjing Military Region (2002-02).

This setup seems to indicate that Jiang will step down in March 2003. It makes little sense to have eight members of the CMC, as Chinese top organs usually comprise an uneven number. Barring a major international crisis or increased tension in the Taiwan Straits, it is most likely that Jiang will step down in March when the NPC meets. Then there will be the possibility of electing a new chairman of the state CMC. It does not make sense to change the party CMC now and then wait until March to change the state $\mathrm{CMC}$, as this would result in a situation where there were two different chairmen.

If Jiang does not step down but instead, as is rumoured in the Western media, stays on for another couple of years, then he will not have fully retired (quantui), but will continue to pull the strings in an arrangement similar to the one that Deng instituted in 1987.

\section{Central Committee (CC)}

The 16th Party Congress elected a new Central Committee consisting of 198 members and 158 alternate members.

There are 112 new members of the full CC (56 percent of total membership). The average age of the new CC is 55 years of age, 0.5 years lower than the 15 th CC. Those below 50 years of age account for more 
than one-fifth of the membership. Predictably, everyone born before 1937 has now retired with the exception of Luo Gan, Ismail Amat, Gao Gangchuan, Li Guixian and Xu Kuangdi. As a new member of the PBSC, Luo Gan had to stay and Gao Gangchuan's position on the CC Military Commission also necessitates a PB seating. Why $\mathrm{Li}$ and $\mathrm{Xu}$, the former mayor of Shanghai, were reappointed is unclear. A number of fifth-generation representatives such as Bo Xilai (53), Xi Jinping (49), Li Keqiang (47) and Zhao Leji (45) were also elected, whereas former CCP party chairman Hua Guofeng finally had to relinquish his seat.

The number of female members has dropped from 7 to 4 ( 2 percent). National minority members number 15 (7.5 percent), which is about the same percentage as in the outgoing CC. It is noteworthy that about 98 percent of the members have an educational background equivalent to a college degree (daxue benke), 6.2 percent higher than the 15th CC and 15.2 percent higher than the 14th CC. In fact, this is the best-educated CC ever in the history of the PRC. Thus the policy to appoint leaders and cadres on the basis of educational background and professional criteria is now being applied at CC elections.

It is also noteworthy that there are representatives from the business world among the new CC alternate members. They include Xie Qihua, president of the Baoshan Iron and Steel Company; Xi Guohua, president of the China Network Communication Corporation; and Zhang Ruimin, the chief CEO of the Haier Group. However, these are all business leaders in the state-dominated sector. Thus rumours that private entrepreneurs might be elected to CC did not come true. Apparently, there was widespread resistance against incorporating private entrepreneurs at this point in time, even though the Party Congress decided to write the 'Three Representations' into the party programme.

\section{Two Aproaches to Chinese Politics}

There are two main positions in evaluating the 16th Congress and its results. The first position sees the outcome as the result of factional politics. ${ }^{4}$ This approach posits that outgoing leaders such as Jiang Zemin, Li Peng and Zhu Rongji have formed networks based on political loyalty. These are personalized networks that serve the interests of the person (patron) heading the network. The network leader looks after the interest of his followers (clients). Jiang Zemin's faction is based in Shanghai and is the strongest. It musters five to six of the nine members of the new PBSC, many regional leaders and leading military figures. Li Peng's network encompasses the ministry of electricity and parts of the NPC 
xitong. Zhu Rongji's faction reputedly consists of leading personnel in the State Economic and Trade Commision and other central organs engaged in economic planning and policy-making. Hu Jintao's network is rooted in the Communist Youth League which Hu headed during the late 1980s. Recently $\mathrm{Hu}$ has also developed strong connections in the Central Party School.

Based on such a factional analysis, Jiang Zemin continues to dominate the PBSC even though he has officially stepped down. As faction head, he will command the loyalty of the people he has promoted. Their presence will help to contain whatever political ambitions Hu Jintao might have.

The second view claims that the Politburo is dominated by consensual decision-making among leading individuals. ${ }^{5}$ The policy process is strongly influenced by the senior members; however, propositions to win assent have to be presented in a reasonable light rather than as a reflection of a single person's fiat or instance of power play. In short, there has been a process of procedural normativization and routinization which will prevent Jiang's patrimonial aspirations from prevailing. This is in fact a return to the round-table model of political decision-making which characterized China before the Great Leap Forward. ${ }^{6}$

Since the mid-1990s new detailed regulations for the selection and appointment of leading cadres have been put in place. In February 1995 the Interim Regulations on the Selection and Appointment of Party and Government Leading Cadres were issued. ${ }^{7}$ They specified clear regulations for the recruitment, appointment and management of leading cadres from the county level and above. Another important document is the Development Programme Concerning the Establishment of a National Party and State Leadership for 1998-2003, which was issued in June 1998. ${ }^{8}$ In June 2000 the Programme to Deepen the Cadre Personnel System was published. ${ }^{9}$ Finally, in July 2002, new Regulations on the Selection and Appointment of Party and Government Leading Cadres were published. They replace the above-mentioned Interim Regulations of $1995 .{ }^{10}$

These documents stipulate clear criteria for the selection and appointment of leading cadres and the mechanisms for promotion within the system. Thus there are clear criteria concerning age, gender and national minority distribution. Educational qualifications are also stressed. Thus an educational background equivalent to a college degree (daxue benke) is now required for leading cadres. New statistics show that already 88 percent of all leading cadres from the important departmental (ju) level and above can now boast of these qualifications. 
The new regulations from July 2002 emphasize that cadres should rise gradually in the system. Thus for promotion to a leading post higher than county level, work experience of holding more than two posts at lower-level organs is generally required. Moreover, candidates promoted to a head post (zheng zhi) from a deputy post are generally required to have worked at the deputy post for more than two years. Clearly, the party wishes to avoid the kind of helicoptering which some cadres experienced during the Cultural Revolution. The new regulations also elaborate on ways to 'democratically recommend' and evaluate leading cadres; on the principles for 'deliberating' candidates; and for making decisions through discussions. There is no doubt that the authorities wish to portray an image of a recruitment and appointment process characterized by clear rules and regulations.

The Development Programme from 1998 stipulates that by the year 2003 every administrative level from the centre down to county and town (zhen) levels should have a leadership line-up consisting of different age groups, ranging from leaders in their sixties to young cadres in their forties. This is to ensure a flexible cadre corps with a so-called rational age composition in the leadership bodies (lingdao banzi). The Development Programme also mentions the establishment of a group of reserve cadres (houbei ganbu), who should be groomed to take over leadership positions.

Recently, age requirements have become the focus of attention. These are associated with the so-called '680 Project' which aims to promote those cadres born in the 1960s who graduated and started working in the 1980s, i.e., young officials below the age of 40 . The ' 680 Project' was launched at the beginning of 2000 which saw several high-level meetings to discuss the issue of selecting and promoting young cadres. In what seems to be a follow-up on the' 680 Project', the Organizational Department has recently required that cadres at the level of section head, division head, and bureau head step down from their leading post at the ages of 52, 55 and 58 respectively. ${ }^{11}$ Whether these new age requirements will be fully introduced remains to be seen. But there is no doubt that there is strong emphasis on this issue in the party apparatus.

It would have been a major setback to the whole process of institutional normativization unfolding since the mid-1990s if Jiang Zemin and his third-generation colleagues had not stepped down from the Standing Committee. In 1997 at the 15th Party Congress, Jiang Zemin had himself been arguing for a 70-year age-limit for re-election to the Standing Committee, reportedly in an attempt to retire his rival Qiao 
Shi. Had he himself violated this norm, it would have created considerable resentment, not only from the new fourth-generation leaders waiting for their turn, but also on the part of retired party elders such as Qiao Shi, Wan Li, Liu Huaqing, Song Renqiong, etc.

\section{Conclusion}

China has recently initiated a major leadership transition - in fact the most comprehensive in the history of the PRC. Thus far it has resulted in the election of a completely new party leadership. Only one out of the nine members of the new PBSC was on the former PBSC and almost two-thirds of the regular members of the Politburo are new. In the spring of 2003 a similar renewal of leadership will take place in top state organs. Thus Jiang Zemin is scheduled to be succeeded as president by $\mathrm{Hu}$ Jintao; Zhu Rongji will most likely pass on his mantle as premier to Wen Jiabao; and Li Peng will make way for Wu Bangguo as chairman of the NPC. The composition of the new leadership is the outcome of an intense power struggle. However, the succession process has for the first time taken place in a peaceful and deliberate manner, in conformity with norms and rules concerning age, educational background, and professional capabilities that have been introduced for lower levels in recent years. In short, a process of institutionalization and normativization has taken place, which bodes well for China's continued political stability.

Dr. Kjeld Erik Brødsgaard is Vice-Director and Associate Professor at the Department of Asian Studies, University of Copenhagen.

\section{NOTES}

1 The following information on personnel changes is drawn from Xinhua News Agency (News.xinhua.net.com); Renmin ribao [People's Daily]; Foreign Broadcast Information Service (FBIS); China aktuell, and Rich Chapman, 'Special Report: China's 16th Party Congress Prospects for a New Direction?' (Virtual Information Center, 15 November 2002). For background information on the new leaders see also Cheng Li, China's Leaders: The New Generation (New York: Rowman \& Littlefield, 2001) and Andrew J. Nathan and Bruce Gilley, China's New Rulers: The Secret Files (New York: New York Review Books, 2002).

2 According to the Financial Times, Zeng Qinghong has been active in promoting administrative and political reform. Thus he is reported to have backed a recent State Council document that suggests that party secretaries in China's 800,000 villages should be elected by direct suffrage. Currently only village chiefs are chosen by direct elections and it will mark a major break with the past if the party also begins to elect its officials by this method rather than by internal selection. See James Kynge, 'Man of Shadows Will be Power behind the Throne', Financial Times, 14 November 2002. 
3 In the 1970s Xinjiang had an alternate member of the Politburo, namely Saifudin, who was elected alternate member of the 10th and 11th Central Committees.

4 On factional politics in China, see Huang Jing, Factionalism in Chinese Communist Politics (Cambridge: Cambridge University Press, 2000), and Lucian Pye, The Dynamics of Chinese Politics (Cambridge, Mass.: Oelgeschlager, Gunn \& Hain Publisher, 1981).

5 See Nathan and Gilley, China's New Leaders.

6 See Roderick MacFarquhar, The Origins of the Cultural Revolution. Vol 1: Contradictions among the People, 1956-57 (London: Oxford University Press, 1974).

7 'Zhonggong zhongyang guanyu yinfa "dang zhengfu lingdao ganbu xuanba renyong gongzuo zanxing tiaoli" de tongzhi' [Notice of the Central Central Committee of the CCP Concerning 'Interim Regulations on the Selection and Appointment of Party and Government Leading Cadres'], 9 February 1995, in Renshigongzuo wenjian xuanbian [Selection of Documents Concerning Personnel Work], Vol. 18 (Beijing: Zhongguo renshi chubanshe, 1996), pp. 13-26.

8 Zhongyang zuzhibu [Organization Department of the CCP],'1998-2003 nian quanguo dang zheng lingdao banzi jianshe guihua gangyao' [Development Programme Concerning the Establishment of a National Party and State Leadership for 1998-2003], 24 June 1998, in Renshi gongzuo wenjian xuanbian, Vol. 21, pp. 90-100.

9 'Shenhua ganbu renshidu gaige gangyao' [The Programme to Deepen the Cadre Personnel System], Renmin Ribao, 21 August 2000.

10 See 'Dang zhengfu lingdao ganbu xuanba renyong gongzuo zanxing' [Regulations on the Selection and Appointment of Party and Government Leading Cadres], Renmin ribao, 24 July 2002.

11 According to Zheng Shiping, the new age requirements mean that officials must step down when reaching a certain age even though they have not yet reached the official retirement age of 60 for section to bureau level leaders. What is intended by the new stipulation is to underline the need for mobility in leadership position at all levels. See Zheng Shiping, 'The Age Factor in Chinese Politics', EAI Background Brief No. 111 (15 January 2002). 